\section{Yen melts down opposition}

\section{Rokkasho}

THE opening of Japan's first commercial facility for the enrichment and reprocessing of nuclear fuel and storage of nuclear waste is destined to go ahead despite local and nationwide opposition.

Last week, local government officials, representatives of the facility and fishermen opposed to the nuclear complex in Rokkasho village on the northern tip of the main island of Japan made it clear to visiting members of the foreign press that the huge amounts of money brought in by the project have effectively quashed almost all local opposition.

The Rokkasho facility, which will cost well over $¥ 1$ million million $(\$ 6,500$ million) when completed in the late $1990 \mathrm{~s}$, is central to Japanese government plans to gain greater independence from foreign suppliers of nuclear fuel. At present nearly all uranium used in Japan's nuclear power plants is of US origin and Japan's spent fuel has to be sent to the United Kingdom and France for reprocessing.

The first facility at Rokkasho, scheduled to open next year, will be a $¥ 180,000$ million plant for the enrichment of uranium. The plant, to be run by Japan Nuclear Fuel Industries (JNFI), a consortium of ten electric power companies, is already 60 per cent complete, according to JNFI officials, and when it reaches full capacity in 2000 the plant will be capable of producing about 20 per cent of Japan's enriched uranium needs.

A low-level waste storage facility also owned by JNFI is expected to open in 1992 at a cost of over $¥ 100,000$ million. With enough space for three million 200-litre drums of waste the facility will be capable of absorbing all low-level waste from Japan's power stations well into the next century. The drums will be buried 12 metres underground, encased in concrete, and monitored for leakage for the next 300 years.

Facilities for reprocessing spent fuel will be built by another consortium of over 100 companies, Japan Nuclear Fuel Service (JNFS), at a cost of $¥ 840,000$ million. JNFS officials hope to start accepting spent fuel from Japanese power stations in 1994 and to begin reprocessing it into uranium and plutonium in 1997 after the fuel has 'cooled down'.

At full capacity, the plant will be able to reprocess the spent fuel from about 30 of the 37 nuclear power reactors currently in operation in Japan. The remaining spent fuel will continue to be sent to the United Kingdom and France for reprocessing.

Japanese high-level waste from the reprocessing plants in Europe will be stored 'temporarily' at Rokkasho for 20 to 30 years from 1993 onwards, according to JNFS officials.
Since the Chernobyl accident in 1986, the Rokkasho facility has become the focal point of a growing nationwide antinuclear power movement. And in December the incumbent village chief in Rokkasho, a strong supporter of the facility, was ousted in the village election by Hiroshi Tsuchida who campaigned for a freeze until the safety of the facility is confirmed.

Last week, Tsuchida, a former supporter of the project, said that he is personally convinced of the plant's safety and once he feels that about 75 per cent of the approximately 12,000 villagers are also convinced he will allow commercial operations to begin (the village chief must sign a safety agreement with JNFS and JNFI before commercial operations can start). Tsuchida estimates that only a few hundred locals are vehemently opposed to the plants and he and fellow village assemblyman Saburo Hashimoto, a supporter of the project, say that JNFS and JNFI should carry out more public relations campaigns to win over the large number of people taking a 'neutral' stance. In line with such calls, the two companies plan to open a new $¥ 3,000$ million ( $\$ 2$ million) public relations centre at Rokkasho next year.

Members of an association of 30 fishermen in the nearby village of Tomari who are opposed to the facility claim that over 50 per cent of Rokkasho villagers are against the project and that many people were deceived by Tsuchida's call for a freeze. But the association says that people cannot openly express opposition because they would be turned away from part-time jobs at farms and the construction site for the facility by village officials who are promoting the project. During the construction peak in the next few years, thousands of locals will be temporarily employed to construct the plants.

And in the Rokkasho area, where men often have to go to Tokyo to find employment as part-time construction labourers, the incentive to refrain from criticizing the project is strong, the Tomari fishermen say. But construction jobs are not the only incentive. Hashimoto says that under a Japanese law designed to promote nuclear power, the Ministry of International Trade and Industry (MITI) will provide Rokkasho with $¥ 18,000$ million ( $\$ 120$ million) in subsidies over a ten-year period. This amounts to about $\$ 10,000$ for every man, woman and child in the village.

The money, which is over four times the village's annual budget, will be used for 96 new village projects including a fish farm, facilities for manufacture of fertilizers, roads, radar facilities for fishermen, a large refrigerated warehouse for storing vegetables, a sports amenity centre and a ski resort. Another $¥ 18,000$ million will

\section{US cracks down on Peru loot \\ Washington}

AFTER a three-year investigation into the desecration and looting of the richest tomb ever excavated in the Western Hemisphere, the US Customs Service has announced a ban on the importation of all archaeological artefacts from the Sipán region of Peru. The US Customs Service said it would seize any artefact that was not accompanied by documentation from the Peruvian government certifying that it had left the country legally. "We are appalled by the desecration of the Sipán Region", said Customs Deputy Commissioner Michael Lane, "but we will end this crime." The discovery in

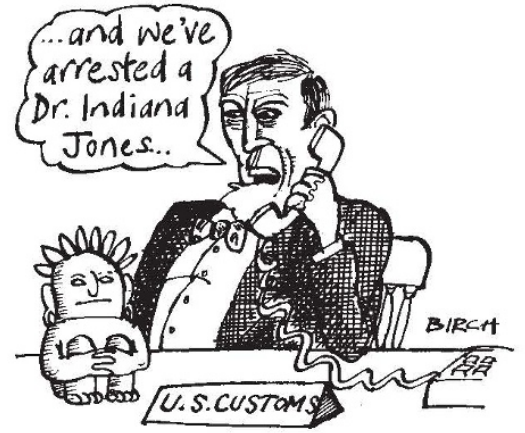

1987 of the graves of the 'Lords of Sipan', as the site is known, led to the 'Peruvian Gold Rush', a frenzy of looting that robbed the tombs of thousands of priceless preColumbian objects. Many of the items eventually made their way to the United States, where they were bought by eager collectors.

In 1988, armed US customs agents searching for illegal Peruvian artefacts raided a group of homes and businesses in Southern California. Among the collectors caught in the raid was physics Nobel laureate Murray Gell-Mann, who had invested tens of thousands of dollars in Sipán art and relics. Gell-Mann then worked with the investigators, and returned several dozen artefacts to Peru.

\section{G. Christopher Anderson}

be given to several villages surrounding Rokkasho, Hashimoto says.

The fishermen's association has filed suit in the Tokyo district court against former prime minister Noboru Takeshita for approving construction of the uranium enrichment facility. The land at Rokkasho was bought from local people by the government-backed Mustu Ogawara Corporation during the $1960 \mathrm{~s}$, on the understanding that it would be used for industrial development. But the fishermen do not expect success. They are pinning their last hopes on support from a nationwide network of anti-nuclear activists and on the success of an anti-nuclear candidate in the elections for governor of Aomori Prefecture to be held next February.

David Swinbanks 